\title{
Sweet Potatoes: Development and Potential as Alternative Food Ingredients in Karanganyar Regency, Indonesia
}

\author{
Yoesti Silvana Arianti*, and Yos Wahyu Harinta \\ Faculty of Agriculture, Department of Agribusiness, Universitas Veteran Bangun Nusantara, \\ Jl. Letjend Sujono Humardani No.1, Sukoharjo 57521, Indonesia
}

\begin{abstract}
Sweet potato is a local food that can reduce dependence on rice and flour consumption. It is the main source of carbohydrates, after rice, cassava, flour and corn. The benefits and potency of sweet potatoes as alternative food needs to be developed, especially in rural areas. However, sweet potato has not been considered as an important and high economic value commodity in Indonesia. Sweet potatoes have been used as food and non-food raw materials in developed countries i.e. noodles, fried sweet potatoes, desserts, confectionery, soy sauce, flour, wine, vinegar, nata de coco, bioethanol and others. Around $89 \%$ of sweet potatoes in Indonesia are cultivated for providing food to rural communities, the rest are used for industrial raw materials and animal feed. The content of sweet potatoes includes carbohydrates, vitamins, and minerals. Yellow/orange sweet potato is rich in beta-carotene and purple sweet potato contains anthocyanin (antioxidants). Sweet potato production is still limited to traditional food that is less attractive compared to flour products. Meanwhile, intermediate products have been developed including flour, instant flour, and starch that can be used as a substitute for flour in pastry products, wet cakes, breads, and noodles.
\end{abstract}

Keyword: Consumption, flour, food diversification, intermediate product

\section{Introduction}

Diversification program has been planned by the Indonesian government since 1974. This is due to the high consumption of rice by the community. Apart from rice, Indonesian people also consume a lot of wheat and various processed wheat. Therefore, the import figures for each year are quite high [1]. Food diversification will provide high benefits if it is able to explore, develop and optimize the utilization of local food sources and local wisdom. Indonesia has various types of food plants that can be grown under any conditions, but their existence is not really considered because they are not a staple food ingredient [2].

Amount one of the local food sources that can be developed is sweet potato. The ideal consumption of sweet potatoes in the Indonesian PPH-Pola Pangan Harapan [Food Hope Pattern] for 2012 is $100 \mathrm{~g}$ per capita $\mathrm{d}^{-1}$. Meanwhile, the real consumption of Indonesian about $40 \mathrm{~g}$ per capita $\mathrm{d}^{-1}$ or around $6 \%$ of ideal consumption. Local food ingredients as

\footnotetext{
*Corresponding author: silvanayusti@gmail.com
} 
Indonesia's wealth need to be preserved for their cultivation and its benefits. At present, the grains group still dominates, so root consumption needs to be encouraged and increased thus the new PPH score reaching 75.5 in 2012 can meet the target score of 93.9 in 2014 and 100 in 2020 [5].

Sweet potato (Ipomoea batatas L. Lam.) is widely cultivated in various countries, including Indonesia, which ranks sixth as an important food ingredient after rice, wheat, potatoes, corn and cassava. Apart from being used as a source of carbohydrate food, sweet potatoes can also be used as industrial raw materials, raw materials for animal feed and alcohol production. This annual plant has a low glycemic index (IG) that is good for diabetics [6]. Food with a low glycemic index can be beneficial in reducing the incidences of chronic diseases [7]. Sweet potatoes may be beneficial to persons with type two diabetes, resulting from the high fiber and manganese content, which could aid in stabilizing blood sugar levels and reduce insulin resistance [8]. In addition, sweet potatoes is one of the Indonesian foodstuff rich in dietary fiber and olygosaccharides [9].

Besides having a role in the supply of food, sweet potatoes also can be used as industrial raw materials and animal feed. But the use of sweet potatoes is limited, that are considered as low products (inferior) such as raw materials for sauces and traditional foods such as boiled/fried sweet potato, kolak, getuk, timus and chips. Therefore, the utilization and consumption of sweet potatoes need to be improved through innovative diversification products that are attractive, nutritious, and have added value with simple technology [10]. The development of sweet potato products requires the support of the continuity and availability of these commodities. This paper aimed to reveal the growth of harvested area, production and productivity of sweet potato. It is expected to provide implications for sweet potato development opportunities in the future to support the success of accelerated food consumption diversification program in Karanganyar Regency.

\section{Methods}

The data and information used in this paper were derived from secondary data from various sources as well as a review of research in the field of food diversification. The main data used was the growth of harvested area, production and productivity of sweet potatoes in Karanganyar Regency, Indonesia.

Data collected by the documentation method that is studying, recording archives or data relating to research problems [11]. This method is carried out by taking data from relevant agencies, including Central Java Province BPS-Badan Pusat Statistik [Indonesia Statistics Agency], Karanganyar Regency Statistics, Karanganyar Regency Agriculture Office, Karanganyar Regency Food Security Agency and other secondary data derived from a review of research. Data were analyzed using a descriptive analysis method which is used to explain the facts and findings of the survey [11].

\section{Results and discussions}

\subsection{Growth of harvested area, production and productivity of sweet potatoes in Karanganyar regency}

\subsubsection{Harvest of sweet potatoes}

Sweet potatoes harvested areas in Karanganyar regency ranks fourth out of 25 districts and cities in Central Java Province. The average of sweet potato harvested areas in Karanganyar 
Regency in the period of 2012 to 2017 was 815 ha. The average share or contribution of the sweet potato harvest area in Karanganyar Regency compared to Central Java Province, Indonesia was $10.67 \%$.

Table 1. Harvested area (ha) of sweet potatoes in Karanganyar Regency in

2012 to 2017

\begin{tabular}{|l|c|c|c|c|c|c|}
\hline & \multicolumn{6}{|c|}{ Year } \\
\hline & $\mathbf{2 0 1 2}$ & $\mathbf{2 0 1 3}$ & $\mathbf{2 0 1 4}$ & $\mathbf{2 0 1 5}$ & $\mathbf{2 0 1 6}$ & $\mathbf{2 0 1 7}$ \\
\hline Harvested area (ha) & 758 & 642 & 860 & 868 & 868 & 894 \\
\hline Share (\%) & 9.48 & 6.41 & 9.50 & 12.27 & 12.27 & 14.08 \\
\hline Average growth per $\mathrm{yr}^{-1}(\%)$ & & & & & & 4.516 \\
\hline
\end{tabular}

Source: Statistics Indonesia, 2013 to 2018

The average growth of sweet potatoes harvested area per year in Karanganyar Regency is $4.52 \%$. Sweet potato harvested area in Karanganyar Regency ranks fourth after Semarang Regency, Magelang Regency and Wonosobo Regency [4]. Sweet potatoes have the advantage that is capable of adapting in less fertile and dry areas.

\subsubsection{Sweet potato production}

In 2012 to 2017 the average sweet potato production in Karanganyar Regency was or 30.26 t. These conditions make Karanganyar Regency the largest contributor of sweet potato production in Central Java Province, Indonesia. The contribution of sweet potato production in Central Java Province was $10.67 \%$. The average annual growth rate for sweet potatoes in Karanganyar Regency is $3.81 \%$.

Table 2. Production ( $\mathrm{t}$ ) of sweet potatoes in Karanganyar

\begin{tabular}{|l|l|l|l|l|l|l|}
\hline & \multicolumn{5}{|c|}{ Year } \\
\hline & 2012 & 2013 & 2014 & 2015 & 2016 & 2017 \\
\hline Production (t) & 32.2130 & 27.0590 & 23.8760 & 31.0760 & 31.0760 & 36.2500 \\
\hline Share (\%) & 19.29 & 14.73 & 13.31 & 20.54 & 20.54 & 24.99 \\
\hline $\begin{array}{l}\text { Average growth } \mathrm{yr}^{-1} \\
(\%)\end{array}$ & & & & & & 3.806 \\
\hline
\end{tabular}

Source: Statistics Indonesia, 2013 to 2018

Sweet potato varieties cultivated by farmers in Karanganyar Regency are cv Manohara and cv Japanese Sweet Potato. Sweet potato yields in Karanganyar Regency were mostly sold entirely by farmers $(79.66 \%)$, amount $16.96 \%$ were sold and those used for self-consumption (not sold) amounted to $3.38 \%$ [11]. Based on an interview with one of the sweet potato farmers in Karanganyar Regency, the current yield of sweet potatoes can reach $40 \mathrm{t} \mathrm{ha}^{-1}$ to $45 \mathrm{t} \mathrm{ha}^{-1}$ with an average selling price of IDR $3000 \mathrm{~kg}^{-1}$. The production cost is around IDR 40000000 thus the income is approximately IDR 12000 $000 \mathrm{mo}^{-1}$ and the profit is IDR 80000000 for a period of $6 \mathrm{mo}$ [12].

\subsubsection{Sweet potato productivity}

Sweet potato productivity in Karanganyar Regency tended to increase with an average of $37.254 \mathrm{t} \mathrm{ha}^{-1}$ during 2012 to 2017 . The average productivity growth per year is $1.55 \%$. 
Table 3. Productivity ( $\mathrm{t} \mathrm{ha}^{-1}$ ) sweet potatoes in Karanganyar Regency 2012 to 2017

\begin{tabular}{|l|c|c|c|c|c|c|}
\hline & \multicolumn{6}{|c|}{ Year } \\
\hline & $\mathbf{2 0 1 2}$ & $\mathbf{2 0 1 3}$ & $\mathbf{2 0 1 4}$ & $\mathbf{2 0 1 5}$ & $\mathbf{2 0 1 6}$ & $\mathbf{2 0 1 7}$ \\
\hline Production (t) & 32.2130 & 27.0590 & 23.8760 & 31.0760 & 31.0760 & 36.2500 \\
\hline Share (\%) & 19.29 & 14.73 & 13.31 & 20.54 & 20.54 & 24.99 \\
\hline $\begin{array}{l}\text { Average growth } \mathrm{yr}^{-1} \\
(\%)\end{array}$ & & & & & & 3.806 \\
\hline
\end{tabular}

Source: Statistics Indonesia, 2013 to 2018

Karanganyar Regency's productivity is in the second position after Brebes Regency. Based on the results of the Balai Penelitian Tanaman Aneka Kacang dan Umbi (Balitkabi) Malang showed that the productivity of sweet potatoes can reach $25 \mathrm{tha}^{-1}$ to $35 \mathrm{tha}^{-1}$ and the productivity of sweet potatoes in Karanganyar Regency can already exceed that number.

\subsubsection{Opportunities for the development of sweet potatoes in supporting the local food based diversification program}

Based on the data, the development of production, productivity and size of sweet potato in Karanganyar Regency is on a positive trend. Continuity of production supports the demand for sweet potatoes for food, feed ingredients, and raw materials for the processing industry (agroindustry). Sweet potato agroindustry needs to be developed because its current product is less varied so it is considered an inferior product. Based on [13], Indonesian and SubSaharan Africa are a like in sweet potato consumption that are mostly consumed by rural communities for breakfast menus or fried, steamed or baked snacks.

The development and existence of local commodity-based agro-industry as an effort to diversify food is very dependent on the availability of main raw materials. Therefore, increasing the production of local commodities needs to be considered along with the development of the agroindustries. Agroindustry, which is usually small and medium scale enterprises, plays an important role in rural social and economic development, plays a role in GDP, and is able to survive times of economic crisis compared to large companies [14].

Challenges for diversification of food based on local food include:

i. Rice is a superior food commodity

The paradigm that develops in society in general is rice as a staple food which has a higher social status because it is a superior commodity. For Indonesians, foods such as potatoes and sweet potatoes are less popular than rice. Moreover, the government provides rice subsidies for the community, allowing an increase in the amount of rice consumption compared to other foodstuffs. [15]

ii. Concept of eating

For the people of Indonesia, rice consumption can be done at least three times to four times a day. Especially for people living in urban areas, consuming rice indicates that their income is higher than others. Therefore, the government can campaign for more profit if people consume staple foods other than rice. For example, sweet potatoes have lots of vitamins and minerals, lower sugar content and higher carbohydrates than rice [16].

iii. Rice is more nutritious and easy to process

Rice has advantages over other carbohydrate sources such as higher energy and protein compared to corn and cassava. In addition, the taste tastes better, easier and more practical and takes less time to process. 
iv. Non-rice food processing technology and its promotion is still limited

Innovation in processing technology, attractive packaging and intensive promotion will produce sweet potatoes that have higher quality, attractive, liked and affordable by the public.

Sweet potatoes is very suitable to be cultivated in the tropics. The opportunity for developing sweet potatoes in Karanganyar Regency is very large due to the relatively stable production and productivity of sweet potatoes. This advantage can be used for complementing feed stuff and supplying raw material of industrial enterprise [17]. But some improvement are needed such as government policies for supporting the growth of the sweet potato industry, to set forth related technical specifications, to carry out research and improvement on new post harvest technology of sweet potato, to improve the operational system of enterprises and explore the market volume products, to do research and development better quality equipments as well as to increase the extraction rate of starch and improve its quality and better food criteria, solve the problem of environmental pollution [18]

The development of agro-industries, especially those that process sweet potatoes, is feasible to be developed by the government. Rural-based agro-industry can reduce the rate of urbanization, can easily be established with minimal skill. They also contribute substantially to the country's gross domestic product, export earnings and development of employment opportunies [19].

Diversification of sweet potato products needs to be done to elevate the degree to superior food, for example processed into flour, noodles, milk, and others [20]. Attractive packaging also needs so the people will be interested in buying sweet potato products. The existence of these steps is expected to help the government program on diversification of food made from local food, thus it can reduce the consumption of rice and flour in Indonesia.

\section{Conclusion}

Based on the results of the study, it concluded that the development of sweet potatoes in Karanganyar Regency is still wide open. Sweet potatoes can be used as an alternative diversification to substitute rice which contains many nutrients that are good for the body. Intensification efforts can be made to increase sweet potato production. In addition, counseling and training on processed sweet potato product preparations can be informed to the public. It aims to make people get a greater profit than just selling fresh sweet potatoes.

\section{References}

1. S. Budijanto, N.D. Yuliana. J. Dev. Sust. Agric. 10:7-14(2015). https://www.jstage.jst.go.jp/article/jdsa/10/1/10_7/_pdf/-char/ja

2. M.A. Trisia, K. Osozawa, H. Bai. How to Feed 311 Million of Indonesian People by 2050? Advancing Local Food Adaptation and Food Security Policy. KnE Life Sciences. ICoA Conferences Proceedings. 3:49-54(2016). https://www.knepublishing.com/index.php/KnE-Life/article/view/417

3. J. Kumara. J. Adv. Manag. Sci. 2,1:65-71(2014). https://www.researchgate.net/publication/275595148_Staple_Food_Balance_Sheet_C oefficient_of_Variation_and_Price_Disparity_in_Indonesia 
4. Badan Pusat Statistik. Provinsi Jawa Tengah dalam Angka 2018 [Central Java Province in Figures 2018] [online] from

https://jateng.bps.go.id/publication/2018/08/16/73e4da7b5902cb91ff591bc7/provinsijawa-tengah-dalam-angka-2018.html (2018). [Accessed on 29 March 2019].

[in Bahasa Indoensia]

5. Pusat Data dan Sistem Informasi Pertanian. Buletin Konsumsi Pangan. 10,2:1-78(2019). [in Bahasa Indonesia].

http://epublikasi.setjen.pertanian.go.id/arsip-buletin/53-buletin-konsumsi/677-buletinkonsumsi-vol-10-no-2-2019

6. A.M. Tangapo, D.I. Astuti, P. Aditiawati. Agric. Nat. Resour. 52,4:309-316(2018). https://www.sciencedirect.com/science/article/pii/S2452316X18300681

7. P.S.B-Singh, C.K. Riley, A.O. Wheatley, H.I.C. Lowe. J. Nut. Metab. 2011:1-6 (2011).

https://www.ncbi.nlm.nih.gov/pmc/articles/PMC3205609/

8. E. Aritonang, A. Siagian, F. Izzati. Int. J. Adv. Sci. Eng. Information Technol. 7,2:580-586 (2017).

https://core.ac.uk/download/pdf/194818326.pdf

9. M. Astawan, S. Widowati. Indonesian J. Agric. Sci. 12,1:40-46(2011). http://ejurnal.litbang.pertanian.go.id/index.php/ijas/article/view/583

10. G. Erlina, R. Yulifianti, M. Jusuf. Jurnal Pangan. 23,2:194-207(2014). [in Bahasa Indonesia].

http://www.jurnalpangan.com/index.php/pangan/article/download/63/57

11. N. Nilamsari. Wacana, 8,2:177-181(2014). [in Bahasa Indonesia] https://pdfs.semanticscholar.org/1d5a/7144eeabb9b9c3d60ccb5461df09d3a02868.pdf

12. J. Hamdani, C. Wirawan. Procedia Economics and Finance. 4:223-233 (2012). https://www.sciencedirect.com/science/article/pii/S2212567112003371

13. J. Low, A. Ball, S. Magezi, J. Njoku, R. Mwanga, M Andrade,K. Tomlins, T.V. Mourik. African J. Food Agric. Nut. Dev. 17,2:11955-11972(2017).

https://www.ajol.info/index.php/ajfand/article/view/155126

14. D.R. Panuju, K. Mizuno, B.H. Trisasongko. J. Saudi Soc. Agric. Sci. 12:27-37(2013). https://www.sciencedirect.com/science/article/pii/S1658077X12000136

15. A. Widyanti, I. Sunaryo, A.D. Kumalasari. JISSAAS. 20,1:93-103(2014). https://agris.fao.org/agris-search/search.do?recordID $=\mathrm{PH} 2014000946$

16. Y. Widodo, S. Wahyuningsih, A. Ueda. Procedia Chemistry. 14:493-500(2015). https://www.sciencedirect.com/science/article/pii/S1876619615000674

17. M. Jusuf, E. Ginting. Energy Procedia. 47:173-179(2014). https://www.sciencedirect.com/science/article/pii/S1876610214002276

18. M.O. Agwu. European J. Sust. Dev. 3,1:101-114(2014). https://www.researchgate.net/publication/304417683_Issues_Challengesand_Prospect sof_Small_and_Medium_Scale_Enterprises_SMEs_in_Port-Harcourt_City

19. H. Kusumayanti, N.A. Handayani, H. Santosa. Procedia Environ. Sci. 23:164-167(2015).

https://www.researchgate.net/publication/271772250_Swelling_Power_and_Water_S olubility_of_Cassava_and_Sweet_Potatoes_Flour 